\title{
DEVELOPMENT INVOLVEMENT OF THE CHURCHES IN EASTERN AND SOUTHERN AFRICA *
}

\author{
Agnes Chepkwony \\ Centre for Contextual Hermeneutics
}

\begin{abstract}
The history of the Church in Africa is even more linked to the general history than elsewhere. This is because the history of Africa is mainly one of the struggle to survive. Under such conditions the Church is inevitably propelled into social action. In the form of NGO's, the Churches have become very important institutions during the past three decades, but they have also suffered as a consequence. This article traces these developments and shows that the Churches have become massive charity organisations. What they need to do, is to become more involved in macro-planning and policy-making.
\end{abstract}

\section{Introduction}

With the attainment of independence at the end of the 1940s in India and Pakistan, the notion of a welfare state began to gain momentum. Thus, the state was envisaged as the main agent of people's welfare ${ }^{2}$. What the notion of a welfare nation/state entailed was that while in the past welfare activities rested primarily on private initiative, individuals and communities, the state would henceforth be at the centre of development activities and social welfare of the people. The state was therefore to become the wheel around which development efforts would revolve.

After the struggle for independence was achieved in Africa, which was from the late 1950s through the 1960s, many nations/states found themselves engulfed in an ideological confrontation that warranted a choice even though the conflict was not of their making, but rather an extension of European and American tension.

Subsequently, the choice of a particular ideology determined the nature of socioeconomic development that a given nation/state would thereafter pursue. The con-

\footnotetext{
* Paper read at the dialogue between Afrikaner theologians and other African theologians in Nairobi, Kenya, 6-13 April 1991.

2. Thomas, M M 1976. Church and State. An ecumenical Inquiry. W C C, Geneva.
} 
frontation between socialism/communism and capitalism also affected the reaction of the church first to the nationalist movements and secondly to the independent states.

We note that during the struggle for independence, the church was afraid of the nationalist movement, thinking that it would become communist. Hence the scenario that evolves from the role of the church, $i$ e one which portrays a divided church - a section of the church supported the struggle while another section opposed the nationalists and there was a middle group that did not support either side ${ }^{3}$. The stance taken by the church during this time was to be reflected in their relationship with the state after independence. The nationalists had knowledge of the power and authority of the church and were also to define the scope of interaction with the church.

I shall in the subsequent subsections attempt to present a historical assessment of the role of the church in national development and the contradictions that the incumbent has encountered along the way.

To begin with, I shall set the stage for the actors by briefly outlining the nature of the colonial state and economy and the place of the colonial church. Thereafter the first three decades of development and the role of the church as one of the major actors will be discussed. This will be followed by an analysis of the church and the African crisis. The paper will conclude with a bird's eye-view of the possible future role of the church in development process.

\section{The colonial heritage}

During the colonial period, we note that the participation of the church varied from country to country and church to church. In some countries the church was the first to establish itself while in others, it was the colonial state. However, if the colonial administration emanated from a predominantly Catholic country like France and Belgium, Protestant churches in such colonies had difficulty running its operations and likewise for Catholics who had to function in British colonies, as it was Protestant churches of British origin that were favoured.

In spite of this constraint, it must be observed that it was the missionary church that was the main carrier of what we today term as social services. The church was heavily involved in creating and sustaining the education system, health services and new agricultural methods; and even imparting new values that were to make way for a new economic system and production. So much so that at independence, the church had a foothold in socio-economic development. The relationship to the state can be said to have been cordial, although not free from conflicts. Yet it should be clearly stated that even with combined efforts of the church and the state in socio-economic development, the economy remained weak and dualistic in nature. The industrial base was either weak or non-existent in some countries, including the private sector. In general, the economy was linked to the international economic system in an un-

3. Chepkwony, A 1987. The Role of NGOs in Development. A case study of NCCK, 1963-1978. Uppsala. 
just manner as reflected in the unequal exchange in international trade. Besides, the mono-culture economy put in place was mainly export-oriented.

Political and economic structures that were operational were anti-people and therefore anti-popular participation - a legacy that was to become characteristic of independent states. Meanwhile the church represented the most organized body within civil society and its structures were to be found at all levels of society from the village to the national level.

The conception of a welfare state was passed on to the African nation/state which was to become the engine of development. But the experiences of the state machinery pointed, on the other hand, to a state that was anti-people and cohesive. The church had played a contradictory role but was nevertheless the most organized body that posed a formidable threat to the authority of the state. The economy was weak, underdeveloped and heavily dependent on the international economic system. What difference then did the ideological choice make and how did it affect the role of the church?

\section{Development decades and the Church}

It is important to note that in those countries which opted for socialist development, most of them nationalised economic ventures, the state became the centre of economic activities with limited private enterprise. Those that adopted capitalist liberal development, witnessed the role of the state reduced to the public sector as the arena of action, while private enterprise and private capital took over the management and control of the economy. It could therefore be argued that the concept of a welfare state was further modified if not changed by the ideological orientation.

Interesting enough however, policies defined during the development decades (1960s, 70s, and 80s), were applied to both socialist and capitalist oriented countries. The only difference may have been the level of official development assistance (ODA) given to the different camps. Arnold Guy's figures indicate that capitalist countries, with the exception of Tanzania, received more aid. Otherwise, countries like Ethiopia, Mozambique and Angola received little. Furthermore, most developed nations did not meet the target of 0.7 percent of their, GNP. Only Scandinavian countries and the Netherlands reached 0.7 to 1 percent. Countries like Britain have only reached 0.31 percent. Aid was perceived as a necessary tool for development in Africa. Both socialist and capitalist countries opted for development plans which set targets to be achieved within a particular period of time. It is worth observing that these plans were devised and even authored with heavy input from the World Bank and other multilateral and bilateral agencies.

It soon became evident that in both socialist and capitalist oriented countries, the state was not developed sufficiently to cope with demands in social and public sectors. In other words, the state did not have enough human and financial resources and as a result it quickly appealed to the church to complement its efforts, which it did. Consequently, the church became a tacit ally of the state. We should, however, qualify that in countries like Ethiopia, Mozambique and Angola and to a limited ex- 
tent Tanzania, the church remained critical of the political ideology of the state ${ }^{4}$. On the whole, the church endorsed government development policies. For example, Kenya and Zimbabwe formulated and implemented their development interventions within the definition of development propagated by the U.N.

The participation of the church in development has been uncritical. It has filled gaps and intervened in places where the government could not. In the case of Zimbabwe, the state has even decided for individual agencies which sub-sectors they should be engaged in. Many of the church programmes have been micro-projects and little if any activity at the macro policy level. It is only in the recent years that the church has seriously tried to question the development policies and theories. In fact, many a church did not have a definite theological premise as a rationale for their programmes ${ }^{5}$.

While the church sailed smooth in development, its relationship to the state regarding political developments has not been ${ }^{6}$ smooth. Questions of governance, political accountability and responsibility have been a source of tension. The state would on its part rather have the church perform its evangelization and development tasks in a narrow sense but not involve itself in political concerns. Hence the classical statement that the church should not engage in politics but rather, it should keep to the pulpit and at most do charity and welfare activities. The attempt to separate evangelism from the total life of human being or for that matter to separate politic from socio-economic levelopment has been the song of many a government, which is a fallacy. It is this separation and compartmentalization of life that has eroded the principles of management, accountability, participation and wholeness.

\section{A false start in development revisited}

During the third development decade, the falsehood of development approaches pursued in both socialist and capitalist orientated countries became evident. Both systems had failed to deliver adequate services to the people; international commodity agreements collapsed, and so did commodity prices.

Environmental degradation became apparent and Africa was hit by famines and droughts one after the other that claimed millions of lives in Ethiopia and the sable belt, to name just a few. The neglect and insufficient incentives to the agricultural sector which is the backbone of Africa, threatened self-sufficiency in food production.

4. Van Bergen, J 1981. Development and religion in Tanzania.

5. Guy, A 1974. Aid in Africa.

6. Guy, A 1985. Aid and the Third World. 
Furthermore, the issue of governance became more acute as it became evident that inherited Western political structures were incompatible with the political mathematical equations of African societies. Consequently, space or effective popular participation decreased, which in turn led to dissatisfaction and civil wars and civil unrest. At the moment the Horn of Africa and Southern Africa are two regions in Africa where civil wars have claimed millions of lives, where the economic infra-structure and production have been destroyed, and where the environment is polluted. Simply put, the wars are a major cause of underdevelopment and have reduced people to relief victims - refugees and displaced persons on the move. Even those sections of the church that were ready to move beyond relief to development and empowerment of the people, cannot do so as they as continuously reduced to relief agents, and whatever little they construct and whatever life they sustain, it is perpetually threatened. Furthermore, those countries that are not necessarily at war, are refugee transit lounges and refugee centres, making it difficult to cope with the relief demands as their economies are fragile and in crisis.

The economic crisis became apparent in the 1980s. Low growth rates, high levels of unemployment, poor terms of trade and deficits in balance of payments, including the impact of the debt crisis. The economic crisis was perceived to have been contributed by the heavy involvement of the state in the economy and poor management of the economy by the state that is riddled with corruption.

Subsequently, the solution proposed noted, inter alia, that the private sector should be encouraged, while the state should roll back even from public expenditure and that parastatal bodies should be privatized.

Privatization as the solution was not quite completed when it was found out that the private sector was weak and sparsely spread to effectively take up the task. Thus, they proposed a combination of the private sector, NGOs and the revamping of the informal sector. Many an external agency have advocated that the salvation of Africa lies in strengthening the work and institutional capacity of NGOs and not the state. There is no doubt that the state machinery needs an overhaul but it should also be noted that policies pursued by the state were designed in collaboration with the very aspects that are blaming the African state. In any case, the NGOs do not have to expand their activities at the expense of the state especially in view of the fact that the NGO agenda is still externally controlled. Besides, NGOs have yet to become rooted and agents of the people; in addition, their operations are small scale and sparsely located in remote areas with no substantial impact or national policy and programme. There is therefore need for the state and NGOs to complement each other.

The fallacy of the new approach is that it is an exogenous proposal just like the previous models. Particularly painful for the church, is the fact that it has become defined by external and internal agents of development as an NGO, an erroneous idea indeed. First, because the definition is not the church's. Secondly, because this definition misrepresents the role and identity of the church which is a spiritual entity whose religious function may or may not embody socioeconomic development. But above all, the task of the church is a spiritual one. Thirdly, the church itself has not refuted this definition and as a result new bills on NGOs by governments are in- 
cluding churches under this category. Yet secular NGOs have but one mission. The NGOs, once development is attained, can fold up and go, or die a natural death. The church, however, will still have a function after fulfilling the development task.

\section{The Churches and the economic crisis}

We have already touched on the impact of the crisis, namely unemployment. School drop-out occurred as a result of the introduction of school fees, hence the re-introduction of illiteracy, even where the problem had been tackled, such as Tanzania. A collapse of the formal economy which has led to the creation and expansion of the informal sector as a means of survival.

The church has woken up late to the crisis, and in many countries the church simply knows that a crisis exists, but not the cause and definite effects of it. In turn, the church is treating symptoms or just doing the business of development as usual, and continually taking over from government those sectors that it cannot service, for example health clinics and hospitals.

For how long shall the church do relief in war zones?

It is time that the church moved decisively beyond its present borders of operation which are micro-projects, to policy level and large scale programmes. In order to be effective and meaningful in relief and development, the church has to transit to peace initiatives. It should actively become a peace broker and reconciler, or else whatever efforts it makes in development, stand to be destroyed. By pursuing peace, the church does not need ${ }^{7}$ to abandon development activities, but it has to recognize the folly of doing relief year in and year out, ${ }^{8}$ constructing bridges and clinics just to be destroyed. But peacemaking should not be one-dimensional - at the top. Different methods and roles should be identified that the church can play at different levels of society. In addition, the church should critically assess the identity crisis it faces by being re-defined by the outsider as an NGO. Moreover, the experience of the church in the development business shows that donors are more ready to fund development programmes than church activities. This has in a way subverted the agenda and identity of the church and it's no wonder that it is now referred to as an NGO.

The dichotomy has in a subtle manner created tensions within the church insofar as staff are concerned and even undermines the authority of the clergy. While clergy and laity who work for church get meagre salaries, development workers on the other hand get relatively better salaries. The professionalisation has been necessary, but it is bound to be detrimental to the ministry of the church. The church is called to teach and preach common values and ethics that promote human dignity.

7. Hallencreutz, C \& Mayo, A 1985. Church and state in Zimbabwe.

8. Chepkwony, S. The Potential of NGOs in National Development: The Case of Zimbabwe. Forthcoming. 